\title{
Effect of Pre Harvest Treatment on Flower Quality and Vase Life of Asiatic lilium cv. Arcachon
}

\author{
Sunita Kumari, Santosh Kumar, C.P. Singh and Vandana Dhami
}

Department of Horticulture, G.B. Pant University Agriculture and Technology,

Pantnagar- 263145, India

*Corresponding author

\section{A B S T R A C T}

Keywords

Foliar spray,

Pre harvest,

Post-harvest and Vase Life.

Article Info

Accepted:

28 August 2017

Available Online:

10 September 2017
An experiment was conducted at Modern Floriculture Centre, G.B. Pant University Agriculture and Technology, Pantnagar to study the effect of pre harvest sprays on flower quality and vase life of Asiatic lilium cv. Arcachon with nine treatments and three replications. The results of the study revealed that two pre harvest foliar sprays of Benzyl adenine @ $100 \mu \mathrm{M}$ significant in basal bud length $(107.72 \mathrm{~mm})$ and bud diameter $(32.95 \mathrm{~mm})$, upper bud length $(73.33 \mathrm{~mm})$ and bud diameter $(22.78 \mathrm{~mm})$, basal flower diameter $(192.80 \mathrm{~mm})$, upper flower diameter $(134.36 \mathrm{~mm})$. The maximum vase life (14.83 days) and water uptake was found $\mathrm{GA}_{3} @ 250 \mathrm{ppm} / \mathrm{L}$ (142.83 ml).

\section{Introduction}

Lilies are great economic important flowering plant that belongs to the genus Lilium can be grown under diverse climatic conditions. They are monocotyledonous, perennial, herbaceous, often bulbous geophytes. During the last decade the lily has gained popularity worldwide among cut flowers and potted flowering plants (Younis et al., 2014). Lilies are used as cut flower, pot plant and plant material used for park, garden and landscape decoration. As a cut flower, the lily is now the fourth most important crop in the world. In India it is used as cut flower and pot plant. In India lilies are grown in the temperate regions of the northern hemisphere and lilies is an export flower crop along with rose, chrysanthemum, carnation, and tulip in Korea. Maintaining the freshness and extending the vase life of cut lilies are very important to the success of this export crop. (Bose, 2003)

A global scale of flower trade demands that cut flowers should preserve their postharvest quality as long as possible, both during the market chain and at the consumer's (RabizaŚwide et al., 2015). Tepal wilting, change in colour and sometimes abscission are the common symptoms that limit the length of vase life of cut lilies (Van and Han, 2011). Another major problem in postharvest life of lilies is early leaf yellowing (Han, 2001). 
There are about 10-30 per cent losses due to post harvest damage in cut flowers. The major problem of the horticulture sector in general and the floriculture industry in particular is the postharvest loss.

Hence the crops are being alive for a certain period but they are liable to deteriorate and loss. It is clear that unless they are preserved the ultimate fate of such produce is senescence and/or death.

However, it is possible to extend the postharvest life of flowers by sprays of different hormones.

\section{Materials and Methods}

The present investigation was carried out at Modern Floriculture Centre of the University G.B. Pant University of Agriculture and Technology; Pantnagar located at $29^{\circ} \mathrm{N}$ latitude, $79.3^{\circ} \mathrm{E}$ longitude in the Tarai belt of Himalayas. The experiment was laid out in completely random block design. The crop was raised under shade net house with uniform standard cultural practices.

Two foliar sprays were done three and two week before the spike harvesting and the bud length $5-7 \mathrm{~cm}$. The pre harvest foliar spray were Control $\left(\mathrm{T}_{1}\right)$ (without any Spray), Benzyl Adenine@50 $\mathrm{MM}\left(\mathrm{T}_{2}\right)$, Benzyl Adenine@100 $\mu \mathrm{M}\left(\mathrm{T}_{3}\right)$, salicylic acid @ 50 $\mu \mathrm{M} / \mathrm{L}\left(\mathrm{T}_{4}\right)$, salicylic acid @ $100 \mu \mathrm{M} / \mathrm{L}\left(\mathrm{T}_{5}\right)$, NAA @ 10 ppm/L $\left(\mathrm{T}_{6}\right)$, NAA @ 20 ppm/L $\left(\mathrm{T}_{7}\right), \mathrm{GA}_{3} @ 250 \mathrm{ppm} / \mathrm{L}\left(\mathrm{T}_{8}\right)$ and $\mathrm{GA}_{3} @ 500$ $\mathrm{ppm} / \mathrm{L}\left(\mathrm{T}_{9}\right)$ with three replication. The spikes were harvested at fully color develop stage in the early morning and put in distilled water. The spikes were harvested with the help of sharp secateurs above ground level 8-9 inch. The spikes length was uniformly maintained i.e. $75 \mathrm{~cm}$. Observations like bud length, bud diameter, flower diameter, vase life and water uptake were recorded.

\section{Results and Discussion}

\section{Number of bud per spike}

The results indicated that the pre harvest foliar spray of BA @ $100 \mu \mathrm{M} / \mathrm{L}$ increased no of bud (4.40) per spike had highest as compare to control (4.05). However, there were no significant differences between the treatments.

\section{Length of basal bud and diameter at spike harvesting stage (mm)}

According to this study the maximum length of basal bud (107.72 $\mathrm{mm}$ ) and bud diameter (32.95 mm) were found pre harvest foliar spray of Benzyl adenine@100 $\mu \mathrm{M} / \mathrm{L}$. The minimum basal bud length $(98.60 \mathrm{~mm})$ and basal bud diameter $(30.22 \mathrm{~mm})$ were found control. Significant increase the diameter of basal bud length was found higher treatments BA@50 $\mu \mathrm{M} / \mathrm{L}(104.56 \mathrm{~mm})$ and SA@100 $\mu \mathrm{M} / \mathrm{L}$ (105.44 mm). However, basal bud diameter was higher found treatment $\mathrm{GA}_{3} @$ 500ppm/L (31.79 mm) (Table 1).

\section{Length of upper bud and diameter at spike harvesting stage $(\mathrm{mm})$}

According to this study the maximum length of upper bud $(73.33 \mathrm{~mm})$ and bud diameter $(22.78 \mathrm{~mm})$ were found pre harvest foliar spray of Benzyla adenine@100 $\mu \mathrm{M} / \mathrm{L}$. The minimum length of basal bud $(52.55 \mathrm{~mm})$ and diameter of bud $(16.82 \mathrm{~mm})$ were found control. Significant increase the diameter of basal bud length was found higher treatments SA@ $100 \mu \mathrm{M} / \mathrm{L} \quad(71.63 \quad \mathrm{~mm}), \quad \mathrm{GA}_{3} @$ 500ppm/L (65.92 mm) and NAA@20 ppm (62.54 mm). However, diameter of upper bud was higher found treatment $\mathrm{GA}_{3} @ 250 \mathrm{ppm} / \mathrm{L}$ $(16.57 \mathrm{~mm})$. The exogenous cytokinins effectively induced floral initiation and development, especially at the early floral initiation and flower development stages. 
Table.1 Effect of preharvest treatment on flower quality and vase life of Asiatic lilium cv. Arcachon

\begin{tabular}{|c|c|c|c|c|c|c|c|c|}
\hline Treatments & $\begin{array}{l}\text { Length of } \\
\text { basal bud at } \\
\text { spike } \\
\text { harvesting } \\
\text { stage (mm) }\end{array}$ & $\begin{array}{c}\text { Diameter of } \\
\text { basal bud at } \\
\text { spike } \\
\text { harvesting } \\
\text { stage }(\mathrm{mm})\end{array}$ & $\begin{array}{l}\text { Length of } \\
\text { upper bud at } \\
\text { spike } \\
\text { harvesting } \\
\text { stage (mm) }\end{array}$ & $\begin{array}{c}\text { Diameter of } \\
\text { upper bud at } \\
\text { spike } \\
\text { harvesting } \\
\text { stage }(\mathrm{mm})\end{array}$ & $\begin{array}{c}\text { Diameter } \\
\text { of basal } \\
\text { flower } \\
(\mathrm{mm})\end{array}$ & $\begin{array}{c}\text { Diameter } \\
\text { of upper } \\
\text { flower } \\
(\mathrm{mm})\end{array}$ & $\begin{array}{l}\text { Vase life } \\
\text { (days) }\end{array}$ & $\begin{array}{l}\text { Water uptake } \\
(\mathrm{ml})\end{array}$ \\
\hline Control & 98.60 & 30.22 & 52.55 & 16.82 & 169.08 & 95.07 & 11.66 & 106.50 \\
\hline BA@50 $\mu \mathrm{M} / \mathrm{L}$ & 104.56 & 31.50 & 62.12 & 17.67 & 174.89 & 112.97 & 12.66 & 124.83 \\
\hline BA@100 $\mu \mathrm{M} / \mathrm{L}$ & 107.72 & 32.95 & 73.33 & 22.78 & 192.80 & 134.36 & 12.83 & 119.83 \\
\hline $\mathrm{SA} @ 50 \mu \mathrm{M} / \mathrm{L}$ & 100.83 & 30.62 & 65.40 & 16.65 & 176.85 & 107.37 & 11.66 & 117.83 \\
\hline $\mathrm{SA} @ 100 \mu \mathrm{M} / \mathrm{L}$ & 105.44 & 31.37 & 71.63 & 18.03 & 190.83 & 112.99 & 14.33 & 139.82 \\
\hline NAA@10 ppm/L & 102.74 & 30.40 & 56.33 & 17.62 & 183.78 & 108.25 & 12.33 & 121.83 \\
\hline NAA @20 ppm/L & 102.90 & 31.27 & 62.54 & 17.56 & 180.51 & 108.20 & 13.00 & 126.00 \\
\hline GA3@ 250ppm/L & 101.43 & 30.87 & 61.83 & 19.04 & 180.76 & 115.19 & 14.83 & 142.83 \\
\hline GA3@ 500ppm/L & 105.84 & 31.79 & 65.92 & 16.57 & 186.15 & 112.68 & 11.66 & 114.66 \\
\hline $\mathrm{S} \mathrm{Em}+$ & 1.475 & 0.494 & 2.905 & 0.723 & 0.723 & 2.571 & 0.565 & 2.183 \\
\hline $\mathrm{CD}$ & 4.421 & 1.481 & 8.711 & 2.169 & 2.169 & 7.709 & 1.694 & 6.545 \\
\hline $\mathrm{CV} \%$ & 2.472 & 2.74 & 7.923 & 6.931 & 6.931 & 3.980 & 7.661 & 3.054 \\
\hline
\end{tabular}


Endogenous cytokinins were higher in early floral initiation and development stages in comparison to the vegetative stage. These results indicate that cytokinins seem to promote the development of flower buds rather than inducing flowering in tuberose (Shuo-Tsang Chang et al., 1999) (Table 1).

\section{Diameter of upper and basal flower (mm)}

According to this study the maximum basal flower diameter was found BA@100 $\mu \mathrm{M} / \mathrm{L}$ $(192.80 \mathrm{~mm})$ as compare to control (169.08 $\mathrm{mm})$. The Significant increase in diameter of basal flower was found higher treatments SA@100 $\mu \mathrm{M} / \mathrm{L}(190.83$ mm), NAA@10 $\mathrm{ppm} / \mathrm{L} \quad(183.78 \mathrm{~mm}), \quad \mathrm{NAA} @ 20 \mathrm{ppm} / \mathrm{L}$ (180.52 mm), GA3@ 250ppm/L (180.76 mm) and $\mathrm{GA}_{3} @ 500 \mathrm{ppm} / \mathrm{L}(186.15 \mathrm{~mm})$ (Table 1).

According to this study the maximum upper flower diameter $(134.36 \mathrm{~mm})$ was found BA @ $100 \mu \mathrm{M} / \mathrm{L}\left(\mathrm{T}_{3}\right)$ as compared to control $\left(\mathrm{T}_{1}\right)$ $(95.07 \mathrm{~mm})$. The significance increase in upper flower diameter was found BA @ 50 $\mu \mathrm{M} / \mathrm{L}(112.97 \mathrm{~mm}), \mathrm{SA} @ 50 \mu \mathrm{M} / \mathrm{L}$ (107.37 mm), SA@100 $\mu \mathrm{M} / \mathrm{L} \quad(112.99 \quad \mathrm{~mm})$, NAA@10 ppm/L (108.25 mm), NAA@20 ppm/L (108.20 mm), GA 3 250ppm/L (115.19 mm) and GA $@ 500$ ppm/L (112.68 mm (Wawrzynczak and Goszczynska, 2000) improved the length and diameter of carnation cut flower by application of 0.05 and $0.1 \mathrm{mM}$ Kinetin. (Kim and Miller, 2008) reported that simultaneous using of GA $4+7$ and BA causes an increase in diameter of Tulip flowers.

Hamidimoghadam et al., (2014) reported that GA3 had a positive effect on qualitative characteristics and longevity of cut flowers. Ramtin et al., (2015) reported that BA@50 $\mu \mathrm{M} / \mathrm{L}$ increase the floret length and flower diameter in carnation. Ramtin et al., (2016) showed that salicylic acid $100 \mu \mathrm{M}$, and benzyl adenine $100 \mu \mathrm{M}$ had more effects than other plant growth hormones (Table 1).

\section{Vase life (Days)}

According to this study the significant maximum vase life was found treatment $\mathrm{GA}_{3} @ 250 \mathrm{ppm} / \mathrm{L}$ (14.83 days) as compare to control (11.66 days).The result suggested that preharvest foliar spray of treatment $\mathrm{SA} @ 100 \mu \mathrm{M} / \mathrm{L} \quad(14.33$ days $)$ was found positive effect on vase life of Asiatic lily cv. Eye Linar. Singh (2005) reported that use of antioxidants in retaining membrane turgidity and for anti-senescence effects during aging has been earlier known. Thus antioxidant property of $\mathrm{GA}_{3}$ contributed to enhance vase life. The similar effect was reported (Kumar and Gupta, 2014) that foliar spray of gibberellic acid 100ppm (16.70 days) over control (12.28 days) in gladiolus. Bharathi and Kumar (2009) reported the similar findings for prolonging vase life of cut tuberose spikes and Umrao et al., (2007) for spike durability in gladiolus. The improvement in vase life may also be due to the translocation of sugar from vase solution via cut spike stem and accumulation in the florets, increases their osmotic concentration and improve their ability to absorb water and maintain turgidity (Halevy, 1976). The maximum vase life (9.33 day) was recorded with bulb dip plus foliar spray of $100 \mathrm{ppm}$ of GA3 followed by the foliar spray of $100 \mathrm{ppm}$ GA3 Alone Khan et al., (2007). Similar results were reported by Dutta et al., (1993) in chrysanthemum, Ichimura and Goto (2000) in narcissus and Gaur et al., (2003) in gladiolus. All the mentioned studies have reported that the beneficial effects of plant growth regulators depend on various parameters such as: cultivar, harvest season, hormone type and applied hormone concentration (Table 1).

\section{Water uptake (ml)}

According to this study the maximum water uptake was found treatment $\mathrm{GA}_{3} @ 250 \mathrm{ppm} / \mathrm{L}$ (142.83 ml) as compare to control (106.50 
$\mathrm{ml}$ ). The positive effect gibberellin hormone has been seen in keeping quality and increasing length of age of anthorium flowers and miniature roses through increasing water absorption rate. Hence, vase life and water uptake was accompanied by ion leakage percentage (Table 1).

Finally it was concluded that maximum basal bud length (107.72 mm), basal bud diameter (32.95 $\mathrm{mm})$, upper bud length $(73.33 \mathrm{~mm})$, upper bud diameter $(22.78 \mathrm{~mm})$, basal flower diameter $(192.80 \mathrm{~mm})$ and upper flower diameter $(134.36 \mathrm{~mm})$ was obtained in preharvest spray of Benzyladenine @ $100 \mu \mathrm{M} / \mathrm{L}$. The maximum vase life (14.83 days) and maximum water uptake was $(142.83 \mathrm{ml})$ were found pre harvest spray of $\mathrm{GA}_{3} @ 250 \mathrm{ppm} / \mathrm{L}$ in Asiatic lily cv. Eye Linar.

\section{References}

Bharathi, T.U., and Kumar, S. 2009. Effect of growth regulators and chemical on postharvest parameters of tuberose cv. Suvasini. Advances in Plant Sciences, 22(1):107-109.

Dutta, J.P., Seemanthini, R., Khader, M. A. and Ramdas, S. 1993. Regulation of flowering by growth regulators in Chrysanthemum (Chrysanthemum indicum Linn.) cv. CO-1. South Indian Hortculture, 41:293-299.

Gaur, G.S., Choudhary, T.C. and Trivedi, J.D. 2003. Effect of $\mathrm{GA}_{3}$ and IAA on growth flowering and corm production in gladiolus cv. Eurovision. Farm Science Journal, 12: 1-3.

Halevy, A.H., 1976. Treatments to improve water balance of cut flowers. Acta Horticulture. 64: 223-230.

Hamidimoghadam, E., Rabiei, V., Nabigol, A. and Farrokhi, J. 2014. Postharvest quality improvement of carnation (Dianthus caryophyllus L.) cut flowers by gibberellic acid, benzyladenine and nano silver. Agricultural Communications. 2(2):28-34.

Han, S.S., 2001. Benzyladenine and gibberellins improve postharvest quality of cut Asiatic and Oriental lilies. Horticulture Science, 36(4):741-745.

Ichimura, K., and Goto, R. 2000. Effect of GA3 on leaf yellowing and vase life of cut Narcissus tazetta var. Chinensis flowers. Journal of Japanese Society of Horticultural Science, 69:423-42.

Khan, F.U., Malik, F.A., Khan, F.A. and Nelofar 2007. Effect of pre-harvest application of $\mathrm{GA}_{3}$ and $\mathrm{PP}_{333}$ as bulb dip and foliar spray on quality and vase life of cut tulip cv. Cassini. Journal of Horticulture Science, 2 (2):156-158.

Kim, H.J., and Miller, W.B. 2008. Effects of GA4+7 and benzyladenine application on post-production quality of 'Seadov' pot tulip flowers. Postharvest Biology and Technology. 47(3):416-421.

Kumar, S., and Gupta, A.K., 2014. Postharvest life of Gladiolus grandiflorus L. cv. Jessica as influenced by pre-harvest application of gibberellic acid and kinetin. Journal of Postharvest Technology, 02 (03):169176.

Meeteren, U. V., 1978. Water relations and keeping quality of cut gerbera flowers. The cause of stem break. Scientia Horticulturae, 8:65-74.

Paull, R.E., and Chantrachit, T., 2001. Benzyladenine and the vase life of tropical ornamentals. Postharvest Biology and Thechnology, 21(11):303310.

Rabiza-Świder, J., Skutnik, E., Jędrzejuk, A., Łukaszewska, A. and Lewandowska, A. 2015. The effect of $\mathrm{GA}_{3}$ and the standard preservative on keeping qualities of cut la hybrid lily 'Richmond'. Acta Scientiarum Polonorum Hortorum Cultus, 14(4): 51- 
64.

Ramtin, A., Kalatejari, S., Naderi, R. and Matinizadeh, M. 2015. Effect of preharvest foliar application of benzyladenine and salicylic acid on Carnation cv. Spray and Standard. Biological Forum - An International Journal, 7: 955-958

Ramtin, A., Kalatejari, S., Naderi, R., and Matinizadeh, M. 2016. Effect of benzyladenine and salicylic acid on biochemical traits of two cultivars of carnation. Journal of Experimental Biology and Agricultural Sciences, 4(4):427-434.

Serek, M., and Andersen, A.S., 1993. AOA and BA influence on floral development and longevity of Potted Victory Parade miniature rose. Horticultural Science, 28(2): 1039-1040.

Shuo-Tsangchang, Wen-Shawchen, ChingYihsu, Hsiao-Ching Y., Bo-Shiun, D., Kuang-Liang, H. 1999. Changes in cytokinin activities before, during and after floral initiation in Polianthes tuberose. Plant Physiolology and
Biochemistry, 37(9):679-684.

Singh, V.P., 2005. Deterioration of membrane during flower senescence in gladiolus and its amelioration with free radical scavenger. Journal of Ornamental Horticulture, 8(1):161-166.

Umrao, V.K., Singh, R.P. and Singh, A.R. 2007. Effect of gibberellic acid and growing media on vegetative and floral attributes of gladiolus. Indian Journal of Horticulture, 64: 73-76.

Van Doorn, W.G., and Han, S.S. 2011.Postharvest quality of cut lily flowers. Post Harves. Biolology and Technology, 62:1- 6 .

Wawrzynczak, A., and Goszczynska, D.M. 2000. Effect of exogenous growth regulators on quality and longevity of cut tulip flowers. Journal of Fruit and Ornamental Plant Research, 8(3):77-78

Younis, A., Hwang, Y. and Lim, K. 2014. Classical vs. Modern Genetic and Breeding Approaches for Lily (Lilium) Crop Improvement: A Review. Flower Research Journal, 22(2):39-47.

\section{How to cite this article:}

Sunita Kumari, Santosh Kumar, C.P. Singh and Vandana Dhami. 2017. Effect of Pre Harvest Treatment on Flower Quality and Vase Life of Asiatic lilium cv. Arcachon. Int.J.Curr.Microbiol.App.Sci. 6(9): 2969-2974. doi: https://doi.org/10.20546/ijcmas.2017.609.364 